\title{
ПЕРСПЕКТИВИ КОДИФІКАЦІЇ ВІЙСЬКОВОГО ЗАКОНОДАВСТВА УКРАЇНИ У РЕАЛІЯХ СЬОГОДЕННЯ
}

\begin{abstract}
КОЛОМІЕЦЬ Владислав Миколайович - кандидат юридичних наук, заступник начальника кафедри правового забезпечення Національного університету оборони України імені Івана Черняховського, полковник юстиції

ORCID ID: 0000-0003-3507-8054

ЗАЙЦЕВ Микола Миколайович - кандидат юридичних наук, начальник науково-дослідного відділу (проблем правового врегулювання питань розвитку, застосування та забезпечення Збройних Сил України) Центрального науководослідного інституту Збройних Сил України, полковник юстиції

ORCID ID: 0000-0003-0322-5910

ЧУНАКОВ Роман Валерійович - старший науковий співробітник науково-дослідного відділу (проблем правового врегулювання питань розвитку, застосування та забезпечення Збройних Сил України) Центрального науководослідного інституту Збройних Сил України,підполковник юстиції

УДК 355.45:351.865, 340.136

DOI 10.32782/EP.2021.4.5
\end{abstract}

Статья посвящена обзору перспектив кодификаиии военного законодательства Украинъ в сегодняиних реалиях.

Авторами обобщенъ имеюшиеся в отечественной научной среде взглядъ относительно современного состояния военного законодательства и перспектив его кодибикации. Констатировано, что связанное с военной сферой законодательство Украинъл включает десятки Законов, которыле, с одной сторонъ, являются отражением динамических процессов, происходящих в обществе, а с другой - порождают ряд противоречий, неоднозначных положений, усложняющих выполнение тех или инъгх правовъхх норм, или создают поле для халатности или даже целенаправленных злоупотреблений. Среди прочего, такое состояние военного законодательства усугубляет последствия гибридной войнъ против Украинъ.

Проанализированъ

подходъ отечественных исследователей к природе кодификации и соответствуюшие положения отдельных законопроектов.

Предложено под кодификачией понимать борму систематизаиии, осуществляемую уполномоченнъими органами государственной власти в процессе законотворчества и подзаконного нормотворчества, с иелью устранения пробелов и противоречий действующего законодательства, результатом которой становится принятие нового как по борме, так и по содержанию кодификачионного нормативно-правового акта.

Осуществлен обзор имеющихся в отечественной науке идей по структуре и наполнению проекта Кодекса оборонъ Украинъл. Акиентировано внимание на наличии в отечественной научной сфере дискуссии о соотношении «военного законодательства» «законодательства в сбере оборонъи».

Учтен соответствуюший зарубежнъий опълт, в частности особенности кодибикации военного законодательства в США. Отмечена необходимость разработки именно Военного Кодекса Украинъг (а не Кодекса оборонъг Украинъг), структура которого, среди прочего, будет сориентирована на регулирование общественнъгх отношений по всем родам войск Вооруженных сил Украинъл.

Ключевые слова: военное законодательство; правовое регулирование; кодибикаиця; национальная безопасность; НАТО; Вооруженнъле силь Украинъ. 


\section{Постановка проблеми та їі зв'язок із важливими науковими чи практичними завданнями}

Нещодавно Україна відзначила 30-ту річницю своєї незалежності. Такий вік, що є критерієм зрілості для людини, з точки зору державотворення можна вважати доволі скромним. Однак, історичне коріння нашої держави сягає традицій сивої давнини, а його витоки губляться у століттях до появи перших літописів. I кожне державне утворення на території сучасної України, з перших же днів свого існування, було змушене проявляти себе як військова сила. Геополітична карта світу, що динамічно змінювалася протягом останнього тисячоліття, раз у раз ставила перед українцями нові виклики, змушуючи їх боронити свою землю та право жити на ній вільно. Не стали винятком і останні кілька років нашої історії.

Збройні Сили України сьогодні потребують всебічної державної підтримки, що має включати в себе і матеріально-технічне забезпечення, і стабільне фінансування, і розробку та виробництво нових видів озброєння, і забезпечення соціально-побутових потреб військовослужбовців. Не останне місце в переліку цих потреб посідає і належне правове регулювання військової сфери, що має не лише відповідати сучасним реаліям та стандартам провідних країн світу, але й передбачати перспективи розвитку військової техніки і військової думки, мати потенціал для подальшого апгрейду, з урахуванням гіпотетичних загроз і небезпек.

Гостра потреба приведення вітчизняного законодавства у відповідність до стандартів розвинутих країн, його систематизації та узагальнення, і актуалізує необхідність дослідження перспектив кодифікації військового законодавства в Україні.

Мета статті - проаналізувати перспективи кодифікації військового законодавства в Україні.

\section{Огляд останніх вітчизняних дослі-} джень у цій сфері

Аналізу проблематики кодифікації законодавства України присвячував ува- гу ряд українських науковців, зокрема: В. Б. Авер'янов, Ю. П. Битяк, І. М. Бондаренко, Е. А. Гетьман, І. П. Голосніченко, Т. О. Коломоєць, В. М. Косович, Н. М. Оніщенко, Н. М. Пархоменко, С. В. Погорєлов, П. М. Рабінович, О. Я. Рогач, О. І. Ющик.

Окремі аспекти піднятої авторами теми щодо кодифікації саме військового законодавства досліджувались такими вітчизняними вченими як В. К. Горовенко, Д. М. Сібільов, Т. А. Стукалін, В. П. Тютюнник. Однак, незважаючи на вкрай високу актуальність дослідження процесів трансформації вітчизняної оборонної сфери та їх правового регулювання, проблематика кодифікації військового законодавства України в сучасних умовах лишається малодослідженою, що й обумовило появу цієї публікації.

\section{Виклад матеріалу дослідження та його основні результати}

«Захист суверенітету і територіальної цілісності України, забезпечення іiі економічної та інформаційної безпеки, є найважливішими функціями держави, справою всього Українського народу» - такий імператив встановлено ст. 17 Конституції України [1]. Окрім того, Основний Закон визначає, що «..оборона України, захист їі суверенітету, територіальної цілісності і недоторканності покладаються на Збройні Сили України. Забезпечення державної безпеки і захист державного кордону України покладаються на відповідні військові формування та правоохоронні органи держави, організація і порядок діяльності яких визначаються законом» [1]. Очевидно, що діяльність відповідних військових формувань i правоохоронних органів держави, регулюються далеко не одним законом, і навіть поверхневий анаᄉіз чинного законодавства, демонструє величезну кількість нормативно-правових актів, на які покладено цю регулятивну місію.

Наразі, пов'язане $з$ військовою сферою законодавство України включає десятки Законів, зокрема, такі як: «Про оборону України» [2], «Про правовий режим воєн- 


\section{Теорія, історія держави і права, конституційне право}

ного стану» [3], «Про Збройні Сили України» [4], «Про військовий обов’язок і військову службу» [5], «Про альтернативну (невійськову) службу» [6], «Про мобілізаційну підготовку та мобілізацію» [7], «Про державний кордон України» [8], «Про правовий режим майна у Збройних Силах України» [9], «Про соціальний і правовий захист військовослужбовців та членів їх сімей» [10], «Про особливості державної політики із забезпечення державного суверенітету України на тимчасово окупованих територіях у Донецькій та Ауганській областях» [11] та багато інших [12].

Така широка палітра Законів та підзаконних нормативно-правових актів, 3 одного боку, $є$ відображенням динамічних процесів, що відбуваються в суспільстві, а з іншого - містить ряд суперечностей, неоднозначних положень, що ускладнюють виконання тих чи інших правових норм, або створюють поле для недбалості чи навіть цілеспрямованих зловживань.

Як доволі слушно зазначають 3 цього приводу В. К. Горовенко та В. П. Тютюнник, численні проблеми й недоліки в оборонному законодавстві особливо гостро проявилися під час розпочатої навесні 2014 р. гібридної війни проти нашої країни [13, с. 18]. Окрім того, після віддмови України (наприкінці 2014 р.) від здійснення політики позаблоковості та визначення курсу на вступ до НАТО постала низка складних проблем, пов'язаних із необхідністю імплементації в національні закони у сфері оборони євроатлантичних термінів, принципів, стандартів, норм, процедур тощо, значних за обсягами та суттєво відмінних за змістом від нині чинних в Україні [13, с. 18-19].

Наразі, ряд дослідників наполягає на необхідності, одночасно 3 проведенням оборонної реформи, розпочати глибоку реформу законодавства у сфері оборони шляхом його кодифікації, спрямованої на систематизацію, уніфікацію, докорінну переробку, оновлення та гармонізацію зі стандартами НАТО $[12 ; 13 ; 14]$. I саме перспективи кодифікації військового законодавства викликають особливу увагу авторів.
Відповідно до сучасної енциклопедичної літератури, дефініція «кодифікація» має латинське походження - «codificatio», де «codex»-збірник законів, a «fatio»- poблю. Вперше зазначений термін було введено у науковий обіг англійським юристом Ієремією Бентамом (XIX ст.), який вважав, що законодавчим актам за своїм змістом належить бути універсальними, доступними й зрозумілими для кожної людини. Цього можна досягти лише в тому разі, якщо звести всі закони в єдиний кодифікований акт, кодекс. Відтак,I. Бентамом було запропоновано створити єдину конституцію для всіх держав [15, с. $432 ; 16$, с. 100]. Відповідно до сучасного Вебстерського словника, «кодифікація» трактується як «систематизація, впорядкування, стандартизація» [17].Однак, таке трактування видається нам аж занадто розмитим.

Значну увагу проблематиці кодифікації законодавства присвятив вітчизняний дослідник Е. А. Гетьман. У ході розгляду теоретичних питань кодифікації адміністративного законодавства він акцентував увагу на тому факті, що національне законодавство не розкриває сутність поняття кодифікації, а також інших суміжних понять (зокрема, систематизації, обліку, інкорпорації, консолідації), що є значним недоліком у формуванні й розвитку правової системи України [16]. Причиною цього стану, на переконання дослідника, $є$ відсутність єдиного закону про нормативноправові акти.

За роки незалежності України мали місце численні спроби ухвалення такого закону: $[18 ; 19 ; 20]$. Характерно, що більшість зазначених законопроєктів містили дані про структуру Кодексів, а деякі з них навіть власні визначення таких дефініцій, як «кодифікація». Так, зокрема, відповідно до подібного законопроєкту від 01.12.2010 № 7409, «кодифікація - це процес зведення різних нормативно-правових актів у єдиний, внутрішньо узгоджений та структурований акт шляхом переробки їх змісту» [19]. Таке трактування, у порівнянні зі словниковим, є дещо детальнішим, однак усе ще лишається надто узагальненим і не 
дає уявлення ні про суб'єктів цього процесу, ні про його мету.

Дещо детальніше кодифікацію трактує вже згадуваний Є. А. Гетьман. На думку дослідника, під кодифікацією законодавства доречно розуміти «форму систематизації, яка здійснюється уповноваженими органами державної влади у процесі законотворчості та підзаконної нормотворчості, результатом чого стає прийняття нового як за формою, так і за змістом кодифікаційного нормативно-правового акту» [16]. Наведений підхід видається нам більш прийнятним i таким, який можна буде взяти за основу, хоча він теж не враховує мотиваційну складову. Відтак, під кодифікацією пропонуємо розглядати форму систематизації, яка здійснюється уповноваженими органами державної влади у процесі законотворчості та підзаконної нормотворчості, 3 метою усунення прогалин і суперечностей чинного законодавства та результатом якої стає прийняття нового як за формою, так і за змістом кодифікаційного нормативно-правового акту.

Власне Кодекси, як результати процесу кодифікації, характеризуються певними особливостями і мають ряд переваг, порівняно $з$ іншими нормативно-правовими актами. Н. М. Пархоменко до особливостей, які притаманні лише Кодексу, відносить наступні: 1) кодекс є відображенням високого рівня впорядкування норм права у певній однорідній сфері суспільних відносин; 2) кодекси характеризуються специфічним предметом і методом правового регулювання; 3) має найвищу юридичну силу в системі галузевих правових актів, яка знаходить прояв у можливості встановлювати, скасовувати або змінювати правові відносини; 4) кодекс має стабільний характер дії [21].

Варто зазначити, що такі особливості кодифікації доволі добре компенсують недоліки чинного українського законодавства у сфері оборони. До останніх сучасні дослідники відносять: надмірну кількість законів, наявність у них серйозних правових прогалин, недосконалість понятійного апарату, а також дублювання, неузгодженість, суперечливість, застарілість і неак- туальність значної кількості їхніх норм; несистематизованість та обмеженість повноти визначення повноважень органів державної влади, основних функцій і завдань органів військового управління, місцевих державних адміністрацій, органів місцевого самоврядування, підприємств, установ та організацій, що діють у сфері оборони України; невизначеність функцій, складу й організації сил оборони, а також основ їх використання, керівництва та управління ними; неадаптованість норм законів, котрі визначають організаційні основи мобілізаційної підготовки і мобілізації, до особливостей і динаміки прояву воєнних загроз у сучасному світі; неефективність визначеної законами системи керівництва силами оборони, насамперед 3 боку Президента України [13; 22]. Цей перелік далеко не вичерпний, однак навіть у такому обсязі він $є$ черговим свідченням на користь нагальної потреби кодифікації військового законодавства. Отож, вважаємо достатньо обгрунтованим твердження про доречність розробки Військового Кодексу України.

Окремої уваги заслуговують підходи до структури та змістовного наповнення перспективного Військового Кодексу. Уже згадувані законопроекти «Про нормативні правові акти» містять не надто відмінний опис пропонованої структури Кодексу. Так, зокрема, відповідно до ст. 12 законопроекту від 14.01.2008 № 1343: «1. Кодекс може складатися із загальної та особливої частин. 2. Загальна частина кодексу може містити: 1) завдання, принципи, визначення понять, основні інститути; 2) спеціальні правові положення (презумпції, преюдиції); 3) положення, дія яких поширюється на всю сферу відносин, які регулюються кодексом; 4) інші загальні нормативні положення, які характеризуються усталеністю і $є$ правовою основою застосування норм особливої частини. 3. Особлива частина кодексу може містити: 1) конкретні правила поведінки суб'єктів суспільних відносин, що є предметом правового регулювання цього нормативно-правового акта; 2) положення, які регулюють окремі види відносин всередині цієї сфери; 3) ви- 


\section{Теорія, історія держави і права, конституційне право}

значення виду і міри юридичної відповідальності. 4. Загальна та особлива частини кодексу повинні бути органічно пов'язані між собою і містити норми відповідно до особливостей предмета правового регулювання. 5. За відсутності поділу на загальну та особливу частини кодекси можуть складатися 3 книг і розділів [20]. Натомість ст. 11 законопроєкту від 01.12.2010 № 7409 визначає: «1. Кодекс складається 3 розділів i глав. Окремий кодекс може складатися 3 книг, які поділяються на розділи та глави. Кодекс може складатися із загальної та особливої частин. 2. У загальній частині кодексу містяться завдання, принципи, визначення термінів, інститутів та інші загальні нормативні положення, які характеризуються підвищеною стабільністю i становлять правову основу для застосування норм особливої частини. 3. В особливій частині кодексу містяться конкретні правила поведінки суб'єктів суспільних відносин, що є предметом правового регулювання такого нормативно-правового акта, визначення правових наслідків невиконання цих правил. 4. Загальна та особлива частини повинні бути органічно пов'язані між собою і містити норми, необхідні і достатні для їх застосування залежно від особливостей предмета правового регулювання» [19]. Тобто в цілому, авторські колективи обох законопроєктів сходяться в думці, що для Кодексу визначальними є: наявність загальної і особливої частини; загальна частина зосереджує сукупність завдань, термінів, понять, положень, які діють на всю окреслену кодексом сферу, тоді як особлива частина визначає конкретні правила поведінки, окремі види відносин та юридичну відповідальність; наповнення кодексу відбувається у форматі статей, розділів та книг (за потреби) (для прикладу, Виборчий кодекс України містить 4 книги, що включають 42 розділи та понад 280 статей [23]).

Ведучи мову про змістовне наповнення Кодексу, варто відмітити наявність широкого та вузького підходів. До прикладу, Д. Сібільов, розмірковуючи про змістовне наповнення перспективного «Кодексу оборони України», пропонує поєднати в ньому такі Закони, як: «Про оборону України», «Про Збройні Сили України», «Про національну безпеку України», «Про Раду національної безпеки і оборони України», «Про Державний кордон України», «Про мобілізаційну підготовку та мобілізацію», «Про військовий обов'язок і військову службу» [12]. Натомість, за широкого підходу Кодекс може поєднати в собі більшість законів, перелічених нами раніше.

Наразі, напевно, найбільш детально опрацювали перспективну структуру й змістовне наповнення Військового Кодексу В. К. Горовенко та В. П. Тютюнник, які, наполягаючи на потребі розробки «Кодексу оборони України», пропонували передбачити як варіант таку його структуру: Розділ I. Загальні положення. Розділ II. Основи оборони України. Розділ III. Повноваження органів державної влади, основні функції та завдання органів військового управління, місцевих державних адміністрацій, органів місцевого самоврядування, підприємств, установ та організацій, обов'язки посадових осіб, права та обов'язки громадян України у сфері оборони. Розділ IV. Підготовка держави до оборони. Розділ V. Сили оборони України. Демократичний цивільний контроль над силами оборони. Розділ VI. Оборонне планування. Розділ VII. Основи мобілізаційної підготовки та мобілізації. Розділ VIII. Воєнний стан. Стан війни. Розділ IX. Використання сил оборони для оборони України, захисту їі суверенітету, територіальної цілісності й недоторканності. Розділ Х. Територіальна оборона. Цивільний захист в особливий період. Розділ XI. Участь України в міжнародних зусиллях із підтримання миру та безпеки, направлення підрозділів Збройних Сил України до інших держав і допуск на територію України підрозділів збройних сил інших держав. Розділ XII. Комплектування сил оборони. Розділ XIII. Військовий обов'язок, військова та альтернативна (невійськова) служба. Розділ XIV. Соціальний та правовий захист військовослужбовців, членів їхніх сімей та осіб, звільнених з військової служби. Розділ XV. Забезпечення законності і правопорядку в силах оборо- 
ни. Розділ XVI. Господарська діяльність Збройних Сил України. Розділ XVII. Засади діяльності оборонної промисловості України. Розділ XVIII. Прикінцеві та перехідні положення [13, с. 21]. Однак, такий підхід видається нам не оптимальним, з огляду на два ключові фактори.

По-перше, пропонована структура Кодексу, як і сама його назва, орієнтована лише на оборону як ключове поняття. Доволі слушно на цьому моменті акцентує увагу П. Богуцький, зазначаючи, що у вітчизняній науковій сфері досі триває теоретичний дискурс стосовно співвідношення «військового законодавства» та «законодавства у сфері оборони». При цьому, на думку дослідника, «подібна дискусія позбавлена сенсу з огляду на вирішення цього питання у правових системах державчленів НАТО, де поняття «military law» - «військове право» застосовується у контексті поняття «військове законодавство», хоча й містить інші змістовні елементи, якими є судова практика, інституційна діяльність відповідних державних органів у сфері оборони, військово-правова доктрина. Водночас, у теорії та практиці діяльності щодо забезпечення національної безпеки у країнах-членах НАТО, у частині, що стосується оборонної політики, використовується поняття «Defense»- оборона, від якого походить поняття «Defender» - захисник» [24].

По-друге, аналогічно до пропозицій Д. Сібільова пропонована структура «Кодексу оборони України» орієнтована, перш за все, на систематизацію окремих сфер суспільних відносин, так чи інакше пов'язаних з безпекою та обороною. При цьому, поза увагою лишаються проблеми регулювання діяльності окремих складових Збройних Сил України. І особливо помітним це $\epsilon$ на фоні підходів, характерних для провідних країн-учасниць НАТО. Так, зокрема, у США місце та роль Збройних сил країни, у відповідності до зведеної кодифікації федерального законодавства, визначаються нормами 10-го розділу Кодексу США, (англ. Title 10 of the United States Code) [25]. При цьому зазначений 10-й розділ містить 5 підрозділів: Підрозділ «А»
- Загальні військові закони (англ. General Military Law) (§§ 101-4881); Підрозділ «B» - Армія СІІА (англ. Army) (\$§ 7001-7842); Підрозділ «С»- Військово-морські сили та Корпус морської піхоти США (англ. Navy and Marine Corps) ( $\S$ 8001-8951); Підрозділ «D»- Військово-повітряні сили (англ. Air Force) (\$§ 9011-9842); Підрозділ «Е - Резервні компоненти (англ. Reserve Components) (\$\$ 10001-18506) [25]. Тобто кожен підрозділ військового розділу Кодексу регулює суспільні відносини щодо певного виду та роду військ (i насамкінець - щодо формування резерву), а вже у складі відповідних підрозділів є частини, присвячені регулюванню організаційних питань, матеріального забезпечення, навчання, підготовки персоналу тощо.

3 огляду на все зазначене, вважаємо за необхідне вести мову про необхідність розробки саме Військового Кодексу України (а не Кодексу оборони України), структура якого, серед іншого, буде зорієнтована на регулювання суспільних відносин щодо Збройних Сил України та інших військових формувань, утворених відповідно до законів України.

\section{Висновки і рекомендації стосовно подальших досліджень}

Узагальнюючи наявні у вітчизняному науковому середовищі погляди щодо перспектив кодифікації військового законодавства, констатуємо, що наразі пов'язане 3 військовою сферою законодавство України включає десятки Законів, що, з одного боку, є відображенням динамічних процесів, які відбуваються в суспільстві, а 3 іншого - породжує ряд суперечностей, неоднозначних положень, що ускладнюють виконання тих чи інших правових норм або створюють поле для недбалості чи навіть цілеспрямованих зловживань.

Проаналізовано підходи вітчизняних дослідників щодо природи кодифікації. Під кодифікацією запропоновано розглядати форму систематизації, яка здійснюється уповноваженими органами державної влади у процесі законотворчості та підзаконної нормотворчості, $з$ метою усунення прогалин і суперечностей чинного 


\section{Теорія, історія держави і права, конституційне право}

законодавства та результатом якої стає прийняття нового як за формою, так і за змістом кодифікаційного нормативно-правового акта.

3 урахуванням досвіду США, акцентовано увагу на необхідності розробки саме Військового Кодексу України (а не Кодексу оборони України), структура якого, серед іншого, буде зорієнтована на регулювання суспільних відносин щодо всіх родів військ Збройних сил України.

У подальшому, окремої уваги дослідників заслуговують питання реалізації кібербезпеки, у рамках кодифікації військового законодавства України.

\section{Література}

1. Конституція України: Закон № 254к/96-ВР від 28 червня 1996 року. Офіційний веб-сайт Верховної Ради України. URL : https://zakon. rada.gov.ua/laws/show/254\%D0\%BA/96$\% \mathrm{D} 0 \% \mathrm{~B} 2 \% \mathrm{D} 1 \% 80$ \# Text

2. Про оборону України: Закон України від 06 грудня 1991р. № 1932XII. Офіційний веб-порал Верховної Ради України. URL : https://zakon.rada.gov.ua/ laws/show/1932-12\#Text

3. Про правовий режим воєнного стану: Закон України від 12 травня 2015р.№ 389-VIII Офіційний веб-порал Верховної Ради України. URL : https:// zakon.rada.gov.ua/laws/show/389-19\#Text

4. Про Збройні Сили України: Закон України від 06 грудня 1991р. № 1934XII. Офіційний веб-порал Верховної Ради України. URL : https://zakon.rada.gov.ua/ laws/show/1934-12\#Text

5. Про військовий обов'язок і військову службу: Закон України від 25 березня 1992p. № 2232-XII. Офіційний веб-порал Верховної Ради України. URL : https://zakon.rada.gov.ua/laws/show/223212 \#Text

6. Про альтернативну (невійськову) службу: Закон України від 12 грудня 1991p. № 1975-XII. Офіційний веб-порал Верховної Ради України. URL : https:// zakon.rada.gov.ua/laws/show/1975-12\#Text

7. Про мобілізаційну підготовку та мобілізацію: Закон України від 21 жовтня 1993p. № 3543-XII. Офіційний веб-порал Верховної Ради України. URL : https:// zakon.rada.gov.ua/laws/show/3543-12\#Text

8. Про державний кордон України: Закон України від 04 листопада 1991р.№ 1777-XII. Офіційний веб-порал Верховної Ради України. URL : https:// zakon.rada.gov.ua/laws/show/1777-12 \#Text

9. Про правовий режим майна у Збройних Силах України: Закон України від 21 вересня 1999p. № 1075-XIV. Офіційний веб-порал Верховної Ради України. URL : https://zakon.rada.gov.ua/ laws/show/1075-14\#Text

10. Про соціальний і правовий захист військовослужбовців та членів їх сімей: Закон України від 20 грудня 1991р. № 2011 XII. Офіційний веб-порал Верховної Ради України. URL : https://zakon.rada.gov.ua/ laws/show/2011-12\#Text

11. Про особливості державної політики із забезпечення державного суверенітету України на тимчасово окупованих територіях у Донецькій та Ауганській областях: Закон України від 18 січня 2018p. № 2268-VIII. Офіційний веб-порал Верховної Ради України. URL : https://zakon.rada.gov.ua/laws/show/226819 \#Text

12. Сібільов Д. Окремі питання кодифікації законодавства у сфері оборони України. Розвиток законодавства України у сфері оборони: проблеми адаптації до стандартів НАТО та шляхи їх вирішення : матеріали Науковопрактичної конференції. м. Київ, 23 квітня 2021 року / упоряд.: П. П. Богуцький, В. Г. Пилипчук, С. О. Дорогих. - Київ, 2021. С. 74-77.

13. Тютюнник В.П., Горовенко В.К. Законодавство у сфері оборони України: стан, проблеми та шляхи реформування. Наука і оборона. 2018. № 1. С. 18-22.

14. Пунда Ю., Пошедін О., Музиченко Д. Евроатлантична інтеграція України у сфері оборони: шляхи удосконалення законодавства. Розвиток законодавства України у сфері оборони: проблеми адаптації до стандартів НАТО та шляхи їх вирішення : матеріали Науковопрактичної конференції. м. Київ, 23 квітня 2021 року / упоряд.: П. П. Богуцький,- 


\section{АНОТАЦІЯ}

СТАТТЮ ПРИСВЯЧЕНО ОГАЯДУ ПЕРСПЕКТИВ КОДИФІКАЦІЇ ВІЙСЬКОВОГО ЗАКОНОДАВСТВА УКРАЇНИ У РЕАЛІЯХ СЬОГОДЕННЯ.

АВТОРАМИ УЗАГАЛЬНЕНО НАЯВНІ У ВІТЧИЗНЯНОМУ НАУКОВОМУ СЕРЕДОВИЩІ ПОГАЯДИ ЩОДО СУЧАСНОГО СТАНУ ВІЙСЬКОВОГО ЗАКОНОДАВСТВА ТА ПЕРСПЕКТИВ ЙОГО КОДИФІКАЦІЇ. КОНСТАТОВАНО, ЩО ПОВ'ЯЗАНЕ З ВІЙСЬКОВОЮ СФЕРОЮ ЗАКОНОДАВСТВО УКРАЇНИ ВКАЮЧАЕ ДЕСЯТКИ ЗАКОНІВ, щО З ОДНОГО БОКУ, Е ВІДОБРАЖЕННЯМ ДИНАМІЧНИХ ПРОЦЕСІВ, ЯКІ ВІДБУВАЮТЬСЯ В СУСПІИЬСТВІ, А З ІНШОГО - ПОРОДЖУЕ РЯД СУПЕРЕЧНОСТЕЙ, НЕОДНОЗНАЧНИХ ПОЛОЖЕНЬ, ЩО УСКААДНЮЮТЬ ВИКОНАННЯ ТИХ ЧИ ІНШИХ ПРАВОВИХ НОРМ АБО СТВОРЮЮТЬ ПОЛЕ ДАЯ НЕДБАЛОСТІ ЧИ НАВІТЬ ЦІАЕСПРЯМОВАНИХ ЗАОВЖИВАНЬ. СЕРЕД ІНШОГО, ТАКИЙ СТАН ВІЙСЬКОВОГО ЗАКОНОДАВСТВА ПОГАИБАЮЕ НАСАДКИ ГІБРИДНОЇ ВІЙНИ ПРОТИ УКРАЇНИ.

ПРОАНАЛІЗОВАНО ПІДХОДИ ВІТЧИЗНЯНИХ ДОСАДНИКІВ ЩОДО ПРИРОДИ КОДИФІКАЦІЇ ТА ВІДПОВІДНІ ПОЛОЖЕННЯ ОКРЕМИХ ЗАКОНОПРОЕКТІВ.

ЗАПРОПОНОВАНО ПЦД КОДИФІКАЦІЕЮ РОЗУМІТИ ФОРМУ СИСТЕМАТИЗАЦІЇ, ЯКА ЗДІЙСНЮЕТЬСЯ УПОВНОВАЖЕНИМИ ОРГАНАМИ ДЕРЖАВНОЇ ВААДИ У ПРОЦЕСІ ЗАКОНОТВОРЧОСТІ ТА ПІДЗАКОННОЇ НОРМОТВОРЧОСТІ, З МЕТОЮ УСУНЕННЯ ПРОГАЛИН I СУПЕРЕЧНОСТЕЙ ЧИННОГО ЗАКОНОДАВСТВА ТА РЕЗУАЬТАТОМ ЯКОЇ СТАЕ ПРИЙНЯТТЯ НОВОГО ЯК ЗА ФОРМОЮ, ТАК І ЗА ЗМІСТОМ КОДИФІКАЦІЙНОГО НОРМАТИВНО-ПРАВОВОГО АКТУ.

ЗДІЙСНЕНО ОГАЯД НАЯВНИХ У ВІТЧИЗНЯНІЙ НАУЦІ ІДЕЙ ЩОДО СТРУКТУРИ ТА НАПОВНЕННЯ ПРОЕКТУ КОДЕКСУ ОБОРОНИ УКРАЇНИ. АКЦЕНТОВАНО УВАГУ НА НАЯВНОСТІ У ВІТЧИЗНЯНІЙ НАУКОВІЙ СФЕРІ ДИСКУСІЇ СТОСОВНО СПІВВІДНОШЕННЯ «ВІЙСЬКОВОГО ЗАКОНОДАВСТВА» ТА «ЗАКОНОДАВСТВА У СФЕРІ ОБОРОНИ».

ВРАХОВАНО ВІДПОВІДНИЙ ЗАРУБІЖНИЙ ДОСВІД, ЗОКРЕМА - ОСОБЛИВОСТІ КОДИФІКАЦІЇ ВІЙСЬКОВОГО ЗАКОНОДАВСТВА В США. НАГОЛОШЕНО НА НЕОБХІДНОСТІ РОЗРОБКИ САМЕ ВІЙСЬКОВОГО КОДЕКСУ УКРАЇНИ (А НЕ КОДЕКСУ ОБОРОНИ УКРАЇНИ), СТРУКТУРА ЯКОГО, СЕРЕД ІНШОГО, БУДЕ ЗОРІСНТОВАНА НА РЕГУАЮВАННЯ СУСПІАЬНИХ ВІДНОСИН ЩОДО ВСІХ РОДІВ ВІЙСЬК ЗБРОЙНИХ СИА УКРАЇНИ.

КАЮЧОВІ САОВА: ВІЙСЬКОВЕ ЗАКОНОДАВСТВО; ПРАВОВЕ РЕГУАЮВАННЯ; КОДИФІКАЦІЯ; НАЦІОНАЛЬНА БЕЗПЕКА; НАТО; ЗБРОЙНІ СИЛИ УКРАЇнИ.
В. Г. Пилипчук, С. О. Дорогих. - Київ, 2021. C. 11-14.

15. Российская юридическая энциклопедия / под ред. А. Я. Сухарева. - М. : Изд. Дом «ИНФРА-М», 1999. -1110 с.

16. Гетьман E. А. Кодифікація адміністративного законодавства України: загальна характеристика, історичні етапи, види / Є. А. Гетьман // Право та інновації. 2017. - № 1. - C. 97-102.

17. Codification. Merriam-Webster. URL : https://www.merriam-webster.com/thesaurus/codification

18. Про нормативні правові акти : проект Закону України // Вісн. Акад. прав. наук України. - 1995. - №4. - С. 141-163.

19. Про нормативно-правові акти: проект Закону України від 01.12.2010№ 7409. Веб-портал Ліга закон. URL : http://search.ligazakon.ua/l doc2.nsf/link1/ JF5PT00A.html

20. Про нормативно-правові акти: проект Закону України від 14.01.2008 № 1343 . Веб-портал Ліга закон. URL : https://ips. ligazakon.net/document/JF11B00A?an=130

21. Пархоменко Н. М. Кодифікація законодавства України на сучасному етапі/Н. М. Пархоменко // Проблеми кодифікації законодавства України : матеріали наук.практ. конф. / [за заг. ред. В. П. Нагребального]. - К. : Ін-т держави і права ім. В. М. Корецького НАН України, 2003. - С. 13.

22. Корж І. Удосконалення законодавства України у сфері оборони: політичний i професійний аспекти. Розвиток законодавства України у сфері оборони: проблеми адаптації до стандартів НАТО та шляхи їх вирішення : матеріали Науковопрактичної конференції. м. Київ, 23 квітня 2021 року / упоряд.: П. П. Богуцький,В. Г. Пилипчук, С. О. Дорогих. - Київ, 2021. С. 121-125.

23. Виборчий Кодекс України: Закон України від 19 грудня 2019p. № 396IX. Офіційний веб-порал Верховної Ради України. URL : https://zakon.rada.gov.ua/ laws/show/396-20\#Text

24. Богуцький П. Сучасний стан і розвиток системи законодавства у сфері оборони України: на шляху до європейської та євроатлантичної інтеграції. Розви- 


\section{Теорія, історія держави і права, конституційне право}

ток законодавства України у сфері оборони: проблеми адаптації до стандартів НАТО та шляхи їх вирішення : матеріали Науковопрактичної конференції. м. Київ, 23 квітня 2021 року / упоряд.: П. П. Богуцький, В. Г. Пилипчук, С. О. Дорогих. - Київ, 2021. С. 20-26.

25. Кодекс Сполучених Штатів Америки (U. S. Code ) URL: https://www.govinfo. gov/app/collection/uscode/2019/title20/ chapter 1
The article is devoted to the review of prospects of codification of the military legislation of Ukraine in the realities of today.

The authors summarize the views available in the domestic scientific community on the current state of military legislation and prospects for its codification. It is stated that the legislation of Ukraine related to the military sphere includes dozens of laws, which on the one hand is a reflection of dynamic processes taking place in society, and on the other - creates a number of contradictions, ambiguous provisions that complicate the implementation of certain legal norms, or also was created a field for negligence or even deliberate abuse. Among other things, this state of military legislation exacerbates the effects of the hybrid war against Ukraine.

The approaches of domestic researchers to the nature of codification and the relevant provisions of individual bills are analyzed.

It is proposed to understand codification as a form of systematization carried out by authorized state authorities in the process of law-making and by-law-making, in order to eliminate gaps and contradictions of current legislation and which results in the adoption of a new codificated normative legal act.

A review of the ideas available in domestic science on the structure and content of the Defense Code of Ukraine is reviewed. Emphasis is placed on the existence of a discussion in the domestic scientific sphere regarding the relationship between "military legislation" and "defense legislation".

Relevant foreign experience is taken into account, in particular, the peculiarities of the codification of military legislation in the United States. Emphasis was placed on the need to develop the Military Code of Ukraine (and not the Defense Code of Ukraine), the structure of which, among other things, will be focused on regulating public relations for all types of troops of the Armed Forces of Ukraine.

Key words: military legislation; legal regulation; codification; National security; NATO; Armed Forces of Ukraine. 